\title{
DESAIN PERKULIAHAN PENGEMBANGAN MATERI AJAR UNTUK SD DENGAN LMS GOOGLE CLASSROOM DI MASA PANDEMIC COVID-19
}

\author{
Dede Trie Kurniawan ${ }^{1}$, Sri Maryanti ${ }^{2}$ dan Nailah Tresnawati ${ }^{1}$ \\ ${ }^{1}$ Jurusan Pendidikan Guru Sekolah Dasar, FKIP Universitas Swadaya Gunung Jati Cirebon \\ ${ }^{2} J u r u s a n$ Pendidikan Biologi, FTK UIN Sunan Gunung Djati Bandung, Indonesia \\ dhe3kurniawan@gmail.com
}

Naskah diterima: 26 Maret, 2020, direvisi: 29 Juni, 2020, diterbitkan: 30 Agustus, 2020

\begin{abstract}
This research is constituted by the phenomenon of Covid-19 that changes the process of learning in universities in Indonesia. Thus, many lectures should develop models of online teaching. This study aims to expand lecturing models in networks through utilizing digital Information Comunication Technology for prospective elementary school teacher. This study attempts to produce methods and designs of digital classroom lectures particularly for thriving teaching materials in elementary schools and escalating metacognition at faculty of education, University of Swadaya Gunung Djati, Cirebon, Jawa Barat. The research method used Development Research with the ADDIE model which is directed to flourish lecture methods in networks for prospective elementary school teacher in exerting digital Information Comunication Technology. This research tries to expand methods and design digital classroom lectures in evolving elementary teaching materials with the Google Classroom Learning Management System and improving their metacognition.
\end{abstract}

Keywords: LMS, Google classroom, Metacognition, Teaching materials, E-Learning

\begin{abstract}
ABSTRAK
Penelitian ini didasarkan pada kondisi dimana perkuliahan pada masa pandemik Covid-19 memerlukan pengembangan model perkuliahan berbasis teknologi (online). Oleh karena itu, penelitian ini berupaya menghasilkan metode dan desain perkuliahan kelas digital terutama dalam pengembangan materi ajar di SD dan pengingkatan metakognisi mahasiswa calon guru di fakultas pendidikan Universitas Swadaya Gunung Djati Cirebon Jawa Barat. Metode penelitian yang digunakan yaitu melalui penelitian pengembangan (Development Research) dengan model ADDIE yang diarahkan untuk mengembangkan metode perkuliahan dalam jaringan untuk mahasiswa calon guru sekolah dasar dalam memanfaatkan teknologi inoformasi dan komunikasi digital. Penelitian ini berupaya untuk mengembangkan metode dan desain perkuliahan kelas digital Pengembangan Materi Ajar SD Dengan LMS (Learning Management System) Google Classroom Untuk Meningkatkan Metakognisi Dan Produk Bahan Ajar Mahasiswa Calon Guru Sekolah Dasar FKIP UGJ.
\end{abstract}

Kata Kunci: LMS, Google classroom, Metakognisi, Bahan ajar, E-Learning

\section{PENDAHULUAN}

Salah satu moto Spirit Universitas Swadaya Gunung Jati (UGJ) dalam singkatan PINTAR yaitu performance yang di maknai sebagai upaya terus menerus dan berkelanjutan melakukan perbaikan - perbaikan dari semua aspek sehingga nilai organisasi / kampus UGJ diharapkan dalam kondisi yang paripurna. Salah satu Aspek yang dipandang masih perlu di tingkatkan adalah pengembangan sistem informasi akademik untuk mahasiswa dalam melakukan perkuliahan dalam jaringan guna meningkatkan efektifitas dan peningkatan literasi teknologi informasi komunikasi untuk civitas akademikanya. Terutama pada masa pandemic Covid-19, pengembangan ini sangat diperlukan agar proses pembelajaran di lingkungan perguruan tinggi menjadi lebih efektif. Selama ini ini UGJ belum memiliki 
sebuah desain perkuliahan dalam jaringan yang terorganisir berjalan dengan baik dan berkesinambungan. Selama ini sistem infromasi yang ada digunakan sebagai sistem administasi bukan sebagai sistem perkuliahan. Pengembangan perkuliahan dalam jaringan untuk UGJ dianggap penitng dikarenakan hasil evaluasi skor akreditasi perguruan tinggi yang dimiliki UGJ masih memberikan nilai yang masih rendah untuk implementasi pembelajaran dalam jaringan untuk perguruan tinggi.

Salah satu solusi sebagai bentuk upaya yang bisa dilakukan untuk meningkatkan performa kualitas akademik mahasiswa adalah dengan menciptakan pembelajaran yang fleksibel, dengan prinsip belajar dimana, kapan dan perangkat apa saja. Hal itu bisa dilakukan dengan memanfaatkan platform atau aplikasi pendukung pembelajaran, seperti Learning Management Systems (LMS). LMS yang dipilih tentunya harus mudah digunakan dan memudahkan belajar mahasiswa. Berkaitan dengan hal ini, Sukarno (Sukarno, 2014) pernah melakukan riset, mengukur kemudahan pamanfaatan aplikasi LMS dalam mendukung pembelajaran Blended. Penelitian ini pernah dilakukan kepada dosen dan mahasiswan sebagai peserta dalam perkuliahan mandiri dengan konsep tutorial secara online. Adapun Indikator yang digunakan berkaitan dengan kemudahan penggunaan aplikasi LMS bagi mahasiswa diungkap dengan cara mengkalkulasi jumlah mahasiswa yang secara mandiri dapat mennjalankan dan mengikuti aplikasi LMS untuk (1) mendownload materi, (2) mengirimkan tugas, dan (3) menyelesaikan kuis. Perkuliahan ini didesain dengan model blended learning dengan jumlah tatap muka 9 kali, pembelajaran secara mandiri dengan tuntunan turotial secara dalam jaringan sejumlah 4 kali, dan pembelajaran yang dilakukan secara mandiri tanpa tutorial satu kali saja. Hasilnya setelah melakukan perampingan prosedur desain pengoperasian aplikasi LMS dan mengoptimalkan kerja sama dosen dengan tim pengelola ICT, kinerja dosen untuk pelaksanaan pembelajaran dengan bantuan aplikasi ini dapat meningkat, yaitu dengan fitur kemudahan mengirimkan materi perkuliahan, memberikan tugas secara online, dan menyelenggarakan kuis. Kedua, upaya pemberian penjelasan keterangan dalam bahasa Indonesia terhadap istilah Inggris yang terdapat pada fitur - fitur aplikasi LMS, penjelasan secara rinci tentang simbol - simbol dan dapat meningkatkan partisipasi mahasiswa dalam mengoperasikan aplikasi LMS dalam mendownload materi, mengunduh/ mengunggah tugas online, serta mengerjakan kuis. Salah Satu Bentuk Aplikasi LMS yang banyak digunakan salah satunya adalah Google Classroom.

Google Classroom adalah Produk aplikasi yang menyediakan layanan menggunakan internet yang dibuat oleh Google sebagai sebuah cerdas berupa system elearning. Layanan ini didesain untuk menolong pengajar membuat dan menyebarluaskan tugas kepada pelajar dengan meminimalisir penggunaan kertas (Hakim, 2016). Google Classroom juga mempunyai kemampuan untuk membuat salinan otomatis dari tugas yang sudah dibuat oleh mahasiswa. Dosen juga dapat mengecek setiap tugas yang dikumpulkan mahasiswa didalam kelas virtual yang sudah dibuat. Manfaat Google Classroom yaitu: a). Persiapan yang mudah dilakukan, dosen dapat menambahkan peserta mahasiswa langsung atau berbagi kode dengan kelasnya untuk menuntun mahasiswa bergabung b). Efektifitas waktu yang baik, Sehingga didapat alur pengerjaan tugas yang sederhana dan tanpa penggunaan kertas yang memungkinkan dosen membuat, memeriksa dan mengevaluasi tugas dengan baik di satu tempat c). Meningkatkan pengelolaan organisasi belajar yang baik, sehingga mahasiswa dapat melihat kinerjanya dihalaman tugas dan semua materi yang diberikan secara otomatis disimpan ke dalam folder yang di integrasikan dengan Google Drive d). Meningkatkan Intensitas komunikasi secra baik, kelas memungkinkan dosen untuk berkomunikasi dalam mengirim pengumuman dan mengajak memulai diskusi secara langsung e.) Aplikasi yang Terjangkau dan aman dalam penggunaannya, Google Classroom 
tidak terdapat iklan, tidak pernah menggunakan konten atau data mahasiswa untuk dijadikan iklan dan aplikasi ini bersifat gratis (Dicky Pratama1), 2016).

Sebagai perguruan tinggi swasta yang berkembang Universitas swadaya Gunung jati cirebon, perlu untuk memperkenalkan konsep pembelajaran secara e-Learning dengan aplikasi Google Classroom ini kepada seluruh akademisi yang ada di Unswagati, terutama para dosen. Oleh karena itu, diperlukan adanya kegiatan pelatihan untuk memperkenalkan sistem e-Learning Google Classroom Unswagati serta bagaimana cara menggunakannya. Adapun Tujuan Penelitian ini untuk mengembangkan model perkuliahan dalam jaringan untuk mahasiswa PGSD dalam memanfaatkan teknologi informasi dan komunikasi secara digital. Penelitian ini berupaya menghasilkan metode dan desain perkuliahan kelas digital Pengembangan Materi Ajar SD Dengan LMS (Learning Management System) Google Classroom Untuk Meningkatkan Metakognisi Dan Produk Bahan Ajar Mahasiswa Calon Guru Sekolah Dasar FKIP UGJ.

Sasaran dari kegiatan pelatihan ini adalah dosen di lingkungan Universitas Swadaya Gunung jati Cirebon. Dari kegiatan ini diharapkan seluruh dosen di lingkungan Universitas swadaya gunung jati cirebon dapat lebih memanfaatkan fasilitas internet kampus untuk kegiatan akademik. Selain itu, dosen juga dapat mengoperasionalkan system program Google Classroom dalam menjalankan perkuliahan dalam jaringan.

Berdasarkan latar belakang yang di jelaskan sebelumnya, maka perlu dilakukan suatu penelitian mengenai Rancang Bangun Desain Perkuliahan Pengembangan Materi Ajar SD Dengan LMS (Learning Management System) Google Classroom Untuk Meningkatkan Metakognisi Dan Produk Bahan Ajar Mahasiswa Calon Guru Sekolah Dasar FKIP UGJ

\section{METODOLOGI}

Penelitian ini merupakan penelitian pengembangan dengan menggunakan model Hanafin dan Peck. Model penelitian pengembangan ini terdiri dari beberapa tahap yaitu fase analisis kebutuhan, fase peracangan dan fase pengembangan serta implementasi (Hanafain \& Peck, 1988). Dalam model ini, unsur penilaian dan revisi perlu diperhatikan dan dijalankan dalam setiap tahap. Model Penelitian Pengembangan Hanafin dan Peck merupakan model peneltiian pengembangan yang lebih berorientasi produk luaran sehingga sesuai digunakan untuk mengembangnkan model perkuliahan dalam jaringan dan instumen penilaian metakognisi dan bahan ajar hasil kreasi mahasiswa calon guru sekolah dasar FKIP UGJ.

Penelitian ini telah dilaksanakan di LPTK kota Cirebon yang menyelenggarakan program studi pendidikan guru sekolah dasar. Subjek penelitian adalah mahasiswa semester III program Sarjana yang sedang mengikuti kuliah pengembangan materi ajar sekolah dasar. Populasi penelitian adalah seluruh mahasiswa calon guru sekolah dasar. Sampel dipilih dengan teknik purposive sampling.

Kegiatan penelitian pengembangan Perkuliahan dalam jaringan Dengan LMS (Learning Management System) Google Classroom Untuk Meningkatkan Metakognisi Dan Produk Bahan Ajar Mahasiswa Calon Guru Sekolah Dasar FKIP UGJ dilaksanakan dalam tahapan yang dijelaskan pada gambar 6 berikut ini. 


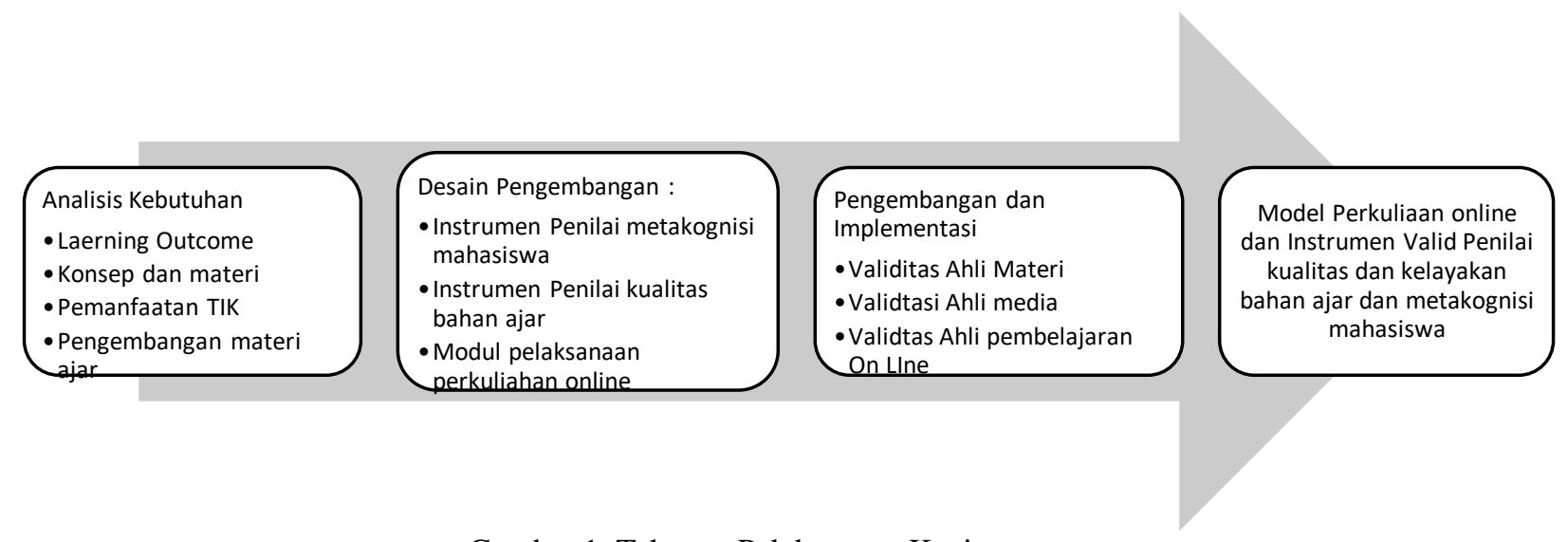

Gambar 1. Tahapan Pelaksanaan Kegiatan

Dalam pengembangan desain perkuliahan dalam jaringan Dengan LMS (Learning Management System) Google Classroom Untuk Meningkatkan Metakognisi Dan Produk Bahan Ajar Mahasiswa Calon Guru Sekolah Dasar FKIP UGJ ini prosedur penelitian pengembangan dijelaskan sebagai berikut:

\section{Analisis Kebutuhan}

Analisis kebutuhan dilakukan dengan upaya mengidentifikasi kebutuhan yang diperlukan dalam mengembangkan instrumen penilaian model dan produk bahan ajar yang akan diselenggarakan dalam jaringan serta metakognisi mahasiswa calon guru sekolah dasar. Pada tahapan ini peneliti melakukan telaah kajian terhadap kebutuhan dalam pengembangan perkuliahan secara On - line dan instrumen yaitu meliputi analisis terhadap kurikulum, rencana kegiatan perkuliahan semester (RKPS), materi, mahasiswa, tugas serta merumuskan tujuan ataupun hasil yang di harapkan dalam pengembangan model perkuliahan dalam jaringan dan instrmen penilaian bahan ajar dan metakognisi mahasiswa. Setelah semua keperluan ditelaah dan identaifikasi Hanafin \& Peck (1988) mendekatkan serta menjalankan penilaian terhadap hasil produk sebelum meneruskan ke fase selanjutnya.

\section{Perancangan}

Pada tahap ini informasi dari tahap analisis dirubah kedalam bentuk dokumen yang akan menjadi tujuan pembuatan model perkuliahan dalam jaringan dan instrumen penilaian bahan ajar dan metakognisi mahasiswa. Tahap desain bertujuan untuk mengidentifikasi dan mendokumentasikan kaidah yang paling baik serta sesuai untuk mencapai tujuan pengembangan model perkuliahan dalam jaringan. Dilakukan Pula Untuk instrumen penialian metakognisi serta produk bahan ajar yang dihasilkan oleh mahasiswa. Pada tahap ini melakukan kegiatan menyusun dokumen berupa komponen pengembangan dari model perkuliahan dalam jaringan dan penilaian untuk rubrik kriteria penilaiannya. Tahap desain ini bisa dijelaskan dalam bentuk story board atau bagan alir yang akan dikembangkan dalam model perkuliahan dalam jaringan dan instrumen penilaian bahan ajar serta metakognisi mahasiswa. Model perkuliahan dalam jaringan dan Instrumen penilaian produk bahan ajar serta metakognisi mahasiswa yang telah selesai di evaluasi oleh ahli pembelajaran pendidikan jarak jauh, ahli materi pembelajaran SD dan ahli multimedia pembelajaran. Hasil kajian para ahli dijadikan masukan untuk lebih menyempurnakan desain yang telah dibuat. Selanjutnya peneliti mengembangkan model perkuliahan dalam jaringan dan instrumen penilaian bahan ajar serta metakognisi mahasiswa sehingga didapat model perkuliahan dan instrumen yang valid Secara internal maupun secara eksternal. 


\section{Pengembangan dan implementasi}

Adapun aktifitas yang dilakukan pada tahap ini diantaranya adalah pengujian dan penilaian. Pada tahap ini dibatasi pada penilaian produk desain perkuliahan dalam jaringan dan penialian secara formatif yaitu uji validitas unutk instrumen penilaian produk bahan ajar serta metakognisi mahasiswa yang dilakukan oleh validator dari ahli pendidikan jarak jauh, ahli pendidikan dasar dan ahli multimedia pembelajaran. Instrumen penilaian bahan ajar dan metakognisi mahasiswa yang telah divalidasi kemudian direvisi dan disempurnakan.

Data hasil validasi yang didapatkan akan di analisis dengan teknik analisis secara presentase. Adapun persamaan rumus yang digunakan untuk menganalisis hasil angket dari validator adalah sebagai berikut:

Keterangan :

$$
P=\frac{\sum x}{\sum x i} \times 100 \%
$$

P : Presentasi Hasil

$\sum \mathrm{x} \quad$ : Jumlah keseluruhan hasil jawaban responden

$\sum x i \quad$ : Jum;ah keseluruhan nilai ideal dalam 1 item

(Arikunto, $2008: 216$ )

Setelah didapatkan hasilnya maka akan dirujuk ke pedoman pengambilan keputusan dari analisis data menggunakan skala kualifikasi. Kriteria kelayakan hasil validasi disajikan dalam tabel 2 berikut ini.

Tabel 2. Kriteria kelayakan dari tiap item

\begin{tabular}{ll}
\hline Tingkat Presentase & Kriteria \\
\hline $25-39$ & Tidak Layak \\
$40-54$ & Kurang Layak \\
$55-69$ & Cukup Layak \\
$70-84$ & Layak \\
$85-100$ & Sangat layak \\
\hline
\end{tabular}

(Slavin, $1992: 78$ )

Berikut merupakan kerangka berpikir yang dikembangkan oleh peneliti dalam penelitian ini:

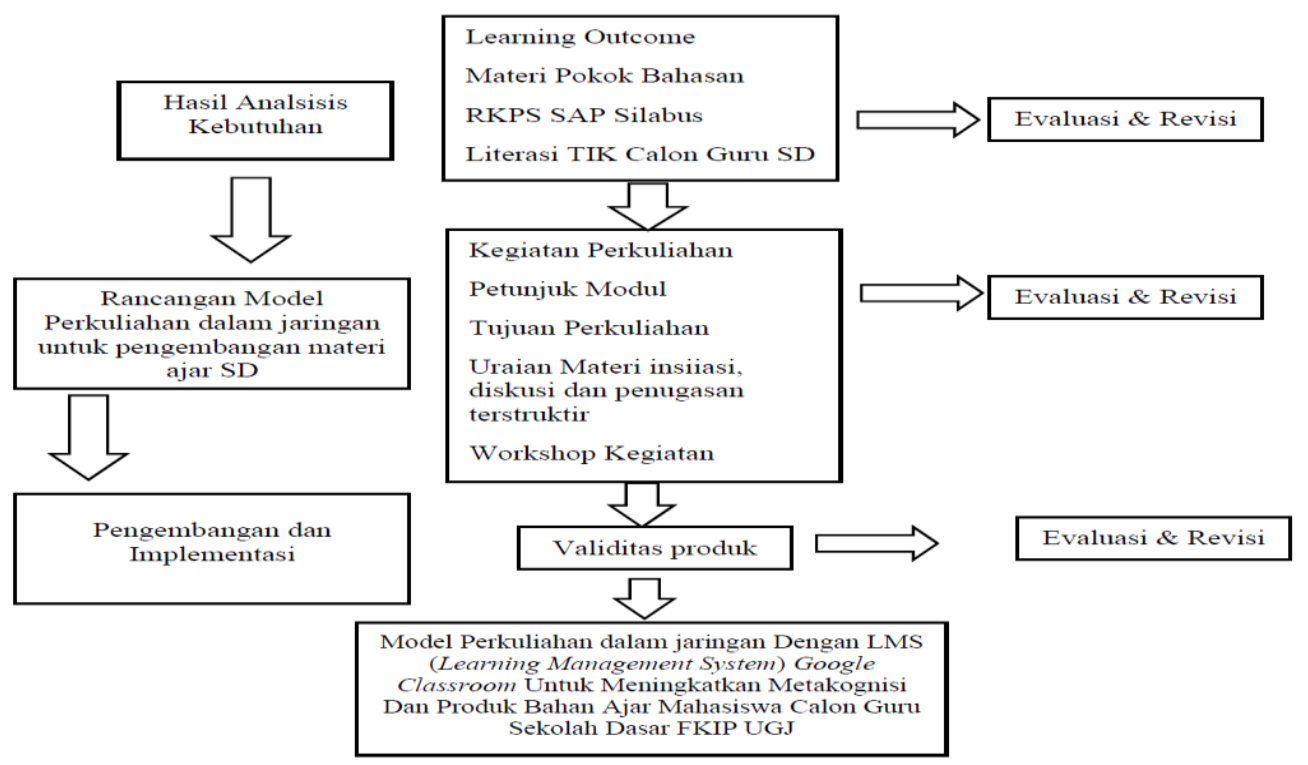

Gambar 2. Kerangka Pemikiran Penelitian 


\section{HASIL DAN DISKUSI}

\section{Desain Perkuliahan Pengembangan Materi Ajar SD melalui LMS Google Classroom}

Desain perkulaihan dalam jaringan menggunakan LMS Google Classroom yang dihasilkan melalui penelitian dan pengembangan yang terdiri dari materi inisiasi, diskusi, tanya jawab dan tugas tersttuktur. Desain inisiasi dalam perkuliahan dalam jaringan dikembangkan mengacu pada RKPS (Rencana Kegiatan Perkuliahan Semester) untuk matakuliah pengembangan materi ajar sekolah dasar. Desain aktifitas dalam perkulaiahn dalam jaringan didesain dalam tiga bentuk aktifitas. (1). Partisipasi pasif : mempelajari bahan - bahan inisiasi dan bacaan tambahan yang diberikan dalam LMS Google Classroom. (2).Partisipasi Aktif : Mendiskusikan topik - topik yang sudah disiapkan oleh dosen (3) Tugas / proyek perkuliahan melalui LMS Google Classroom. Bentuk Desain Perkuliahan dapat dilihat pada gambar 2 berikut ini.

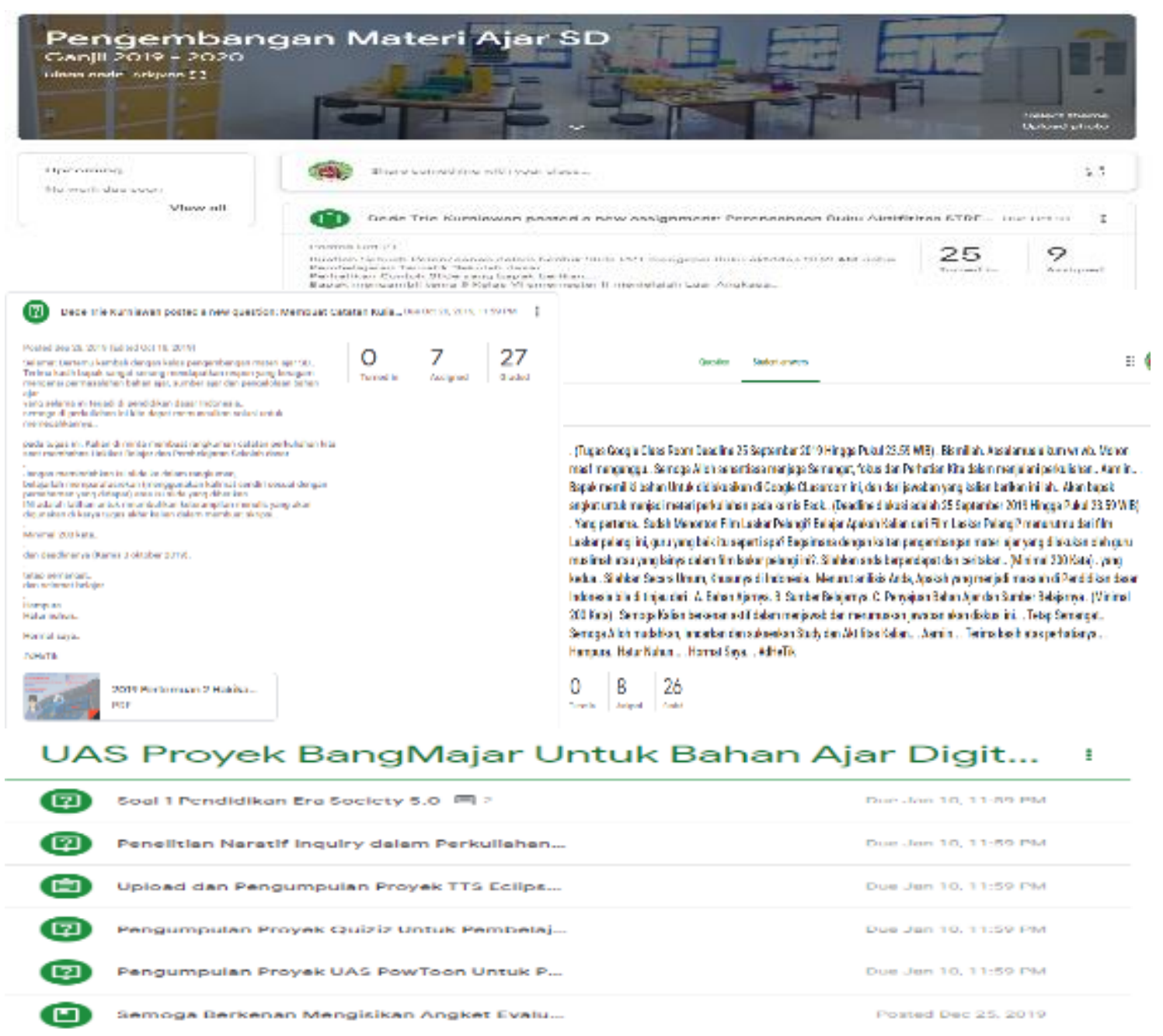

Gambar 2. Desain Perkuliahan Pengembangan Materi Ajar Sekolah Dasar yang mencangkup Inisiasi,Aktifitas dan Tugas proyek

Perkuliahan dalam jarimgan untuk matakuliah pengembangan materi ajar sekolah dasar ini diikuti oleh 26 mahassiwa dengan 1 dosen dan 3 Supervisor untuk mengawasi dan membimbing jalanya perkuliahan. Supervisor terdiri atas 1 Orang rekan dosen sejawat, 1 ketua program studi dan 1 Orang dari divisi unit pengembangan TIK Fakultas. Berdasarkan 
rekam data peserta kegiatan perkuliahan dalam jaringan di matakuliah ini Perserta Cenderung terkateogri aktif. Hal ini dapat dilihat dari partisipasi mahasiswa dalam diskusi dan penyelesaian tugas serta proyek akhir melalui LMS Google Classroom.

\section{Desain Perkuliahan Pengantar Pendidikan melalui LMS Google Classroom}

Desain perkulaihan dalam jaringan menggunakan LMS Google Classroom yang dihasilkan melalui penelitian dan pengembangan yang terdiri dari materi inisiasi, diskusi, tanya jawab dan tugas tersttuktur. Desain inisiasi dalam perkuliahan dalam jaringan dikembangkan mengacu pada RKPS (Rencana Kegiatan Perkuliahan Semester) untuk matakuliah pengantar pendidikan. Desain aktifitas dalam perkulaiahn dalam jaringan didesain dalam tiga bentuk aktifitas. (1). Partisipasi pasif : mempelajari bahan - bahan inisiasi dan bacaan tambahan yang diberikan dalam LMS Google Classroom. (2).Partisipasi Aktif : Mendiskusikan topik - topik yang sudah disiapkan oleh dosen (3) Tugas / proyek perkuliahan melalui LMS Google Classroom. Bentuk Desain Perkuliahan dapat dilihat pada gambar 3 berikut ini.

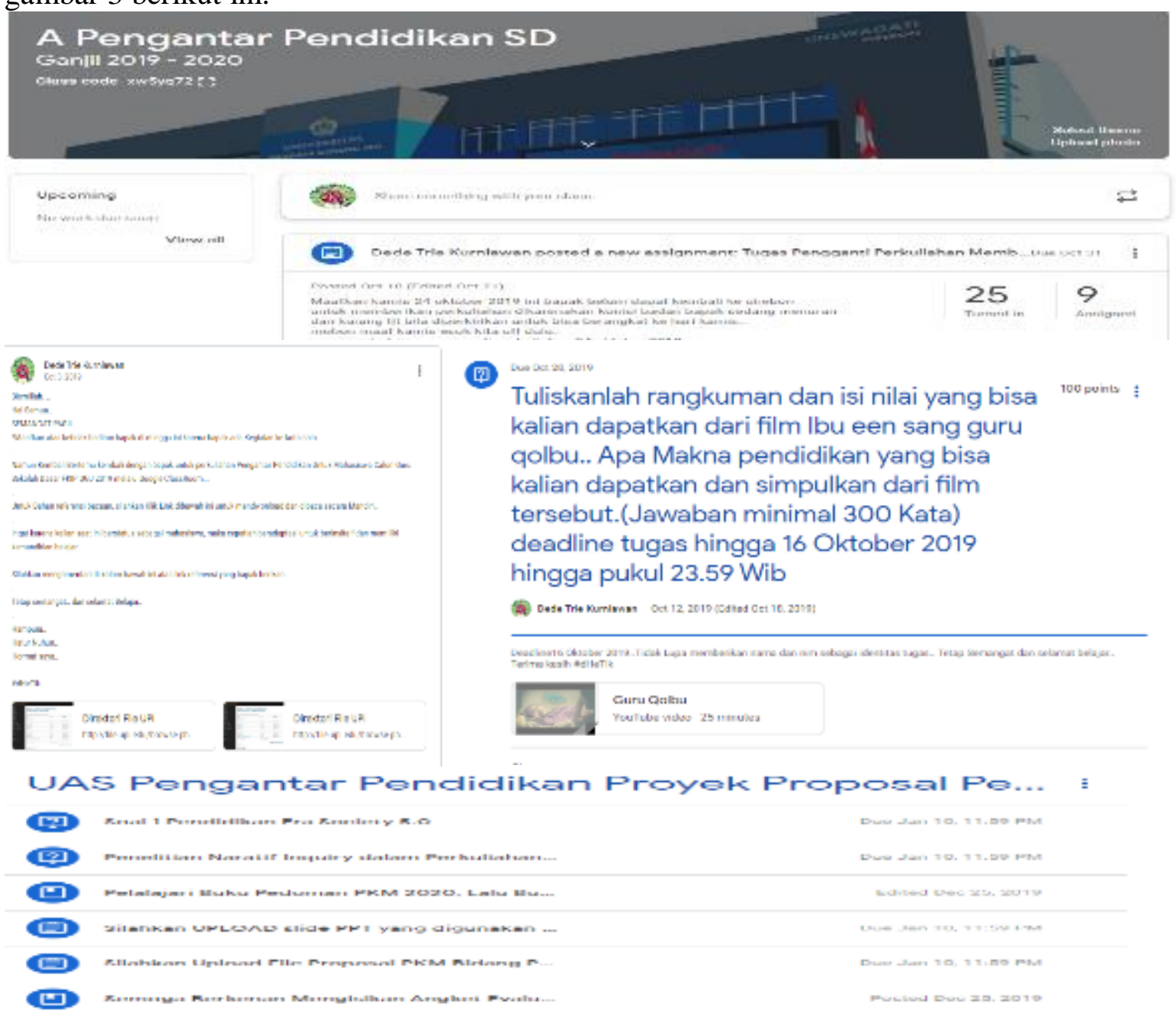

Gambar 3. Desain Perkuliahan Pengantar Pendidikan yang mencangkup Inisiasi,Aktifitas dan Tugas proyek

Perkuliahan dalam jarimgan untuk matakuliah pengembangan materi ajar sekolah dasar ini diikuti oleh 28 mahassiwa dengan 1 dosen dan 3 Supervisor untuk mengawasi dan membimbing jalanya perkuliahan. Supervisor terdiri atas 1 Orang rekan dosen sejawat, 1 
ketua program studi dan 1 Orang dari divisi unit pengembangan TIK Fakultas. Berdasarkan rekam data peserta kegiatan perkuliahan dalam jaringan di matakuliah ini Perserta Cenderung terkateogri aktif. Hal ini dapat dilihat dari partisipasi mahasiswa dalam diskusi dan penyelesaian tugas serta proyek akhir melalui LMS Google Classroom.

\section{Hasil Validasi Pakar Terhadap Perkuliahan Dalam Jaringan Yang Dikembangkan}

Sebelum Produk Desain Perkuliahan Pengembangan Materi Ajar SD Dengan LMS

(Learning Management System) Google Classroom ini digunakan, maka sebelumnya terlebih dahulu produk model ini di nilai oleh tiga ahli pakar dalam bidang pendidikan dasar, media pembelajaran dan pendidikan calon guru untuk memastikan kebaikan dan kelayakan penggunaanya dalam kegiatan pembelaran dalam jaringan untuk mahasiswa. Tabel 2 merangkum hasil - hasil validasi ahli terhadap produk pengembangan Desain Perkuliahan Pengembangan Materi Ajar SD Dengan LMS (Learning Management System) Google Classroom untuk mahasiswa calon guru sekolah dasar.

Table 2. Rekapitulasi Hasil Validasi Ahli Terhadap produk Desain Perkuliahan Pengembangan Materi Ajar SD Dengan LMS (Learning Management System) Google Classroom untuk mahasiswa calon guru sekolah dasar.

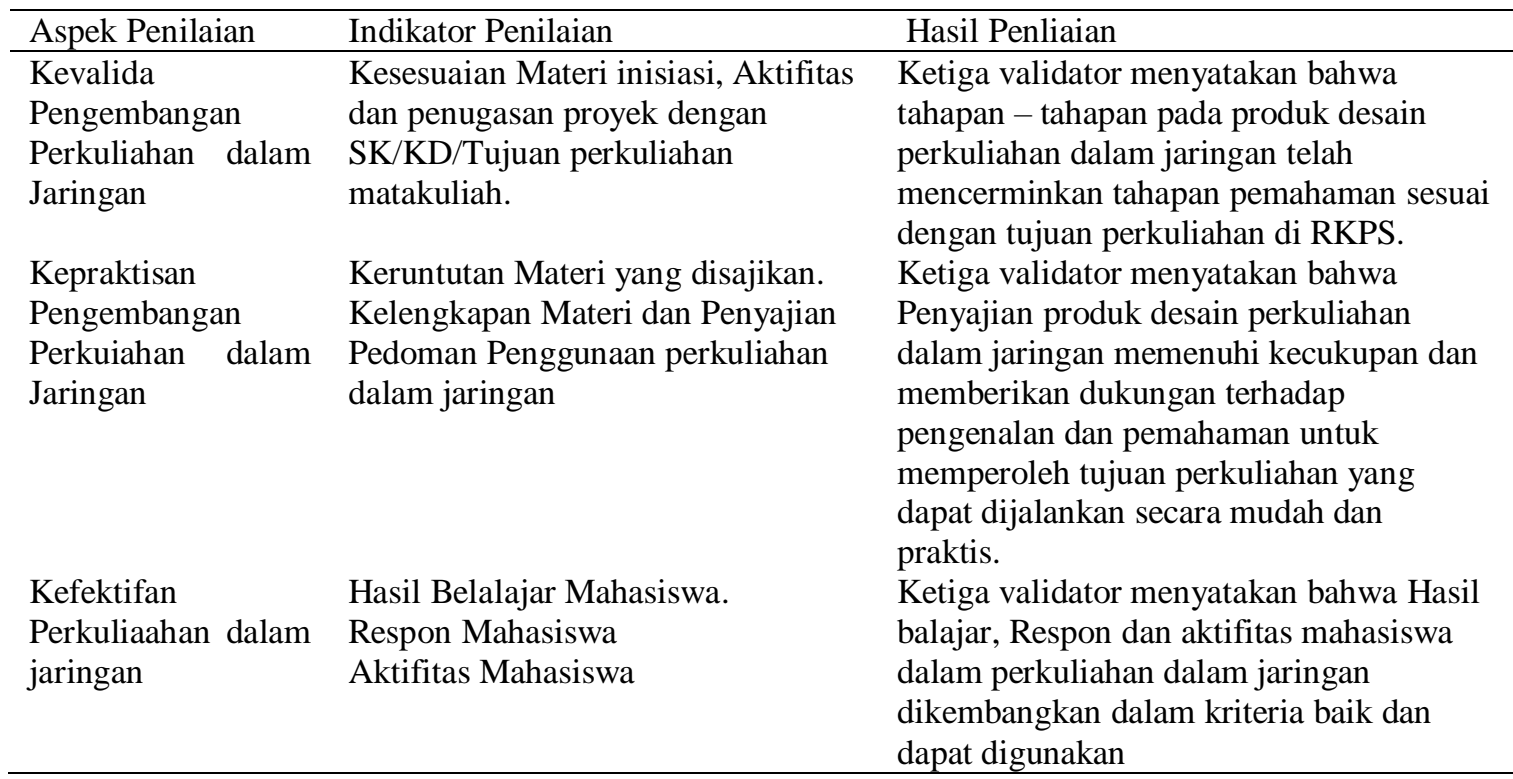

Adapun kendala dalam penelitian yang akan ditemukan, yaitu kendala selama proses desain model pembelajaran, menyangkut implementasi desain model pembelajaran di kelas dan kesiapan yang dibutuhkan untuk mendapatkan desain pembelajaran. Kelemahan penelitian yang dipaparkan adalah kelemahan akibat keterbatasan jalanya penelitian, khususnya kelemahan pada proses saat uji coba. Selain itu diungkapkan juga alasan munculnya kelemahan dan alternatif solusi yang dapat dijalankan serta ditempuh untuk meminimalkan kelemahan tersebut.

\section{Respon Mahasiswa terhadap Perkuliahan dalam Jaringan yang dikembangkan}

Respon mahasiswa pada pembelajaran dengan menggunakan Google Classroom di matakuliah pengembangan materi ajar sekolah dasar seperti tersaji pada gambar 3 berikut ini. 


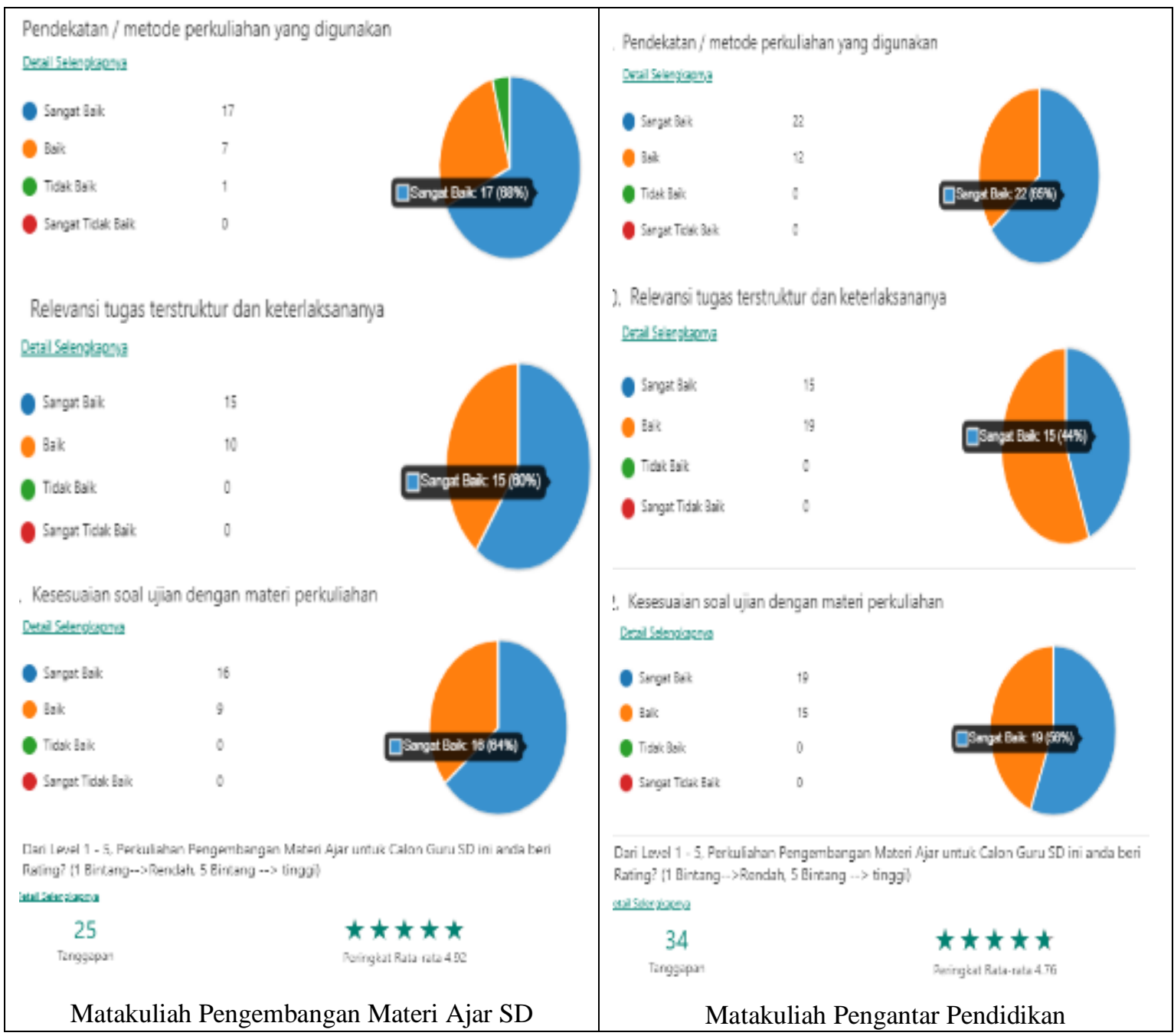

Gambar 3. Respon Mahassiwa terhadap pelaksanaan perkuliahan dalam jaringan pengembangan materi ajar Sekolah dasar

Penelitian ini juga menunjukan performa Google Classroom (GCR) menunjang pembelajaran pada matakuliah pengembangan materi ajar SD karena dengan GCR ini mahasiswa mendapat kemudahan untuk penyimpanan dokumen seperti materi perkuliahan maupun tugas yang dikirim lewat GCR, sehingga jika mahasiswa tidak sempat untuk mencetak dokumen yang mereka perlukan, mereka dapat mengakses melalui GCR nya. Selain itu, mahasiswa juga mendapat kemudahan untuk medapatkan informasi pengumuman yang disampaikan oleh dosen secara cepat sehingga penyampaian informasi menjadi efektif dan efisien dari pemanfaatan waktu. Hal ini sesuai dengan penelitian yang diungkapkan oleh (Dhia Ghina Ramadhani Putri S, 2017) yang menyatakan bahwa media GCR efektif digunakan oleh dosen untuk menyampaikan materi kepada mahasiswa.

Pemanfataan LMS Google Classroom ini sebagai implementasi bentuk ruang belajar di dunia maya yang memfasilitasi kolaborasi belajar antara mahasiswa dan dosen yang dilakukan secara Asynchronous dimana pembelajaran dapat dilakukan dimana saja dan kapan saja. Stretegi yang digunakan dalam matakuliah pengembangan materi ajar melalui LMS google classroom ini adalah memposisikan Google classroom menjari ruangbelajar mandiri dan kolaboratif. Ruang belajar mandiri ini dimaksudkan bahwa mahasiswa dapat belajar mandiri kapan saja dimana saja dengan kondisi kecepatan belajar masing masing. Melalui google classroom ini dosen memberikan sajian konten yang menstimulasi awal 
kegiatan belajar mahasiswa mengenai pemanfaatan teknologi dalam pengembangan materi pembelajaran sekolah dasar. selain itu disajikan pula konten mengenai pemanfaatan pendekatan STEM untuk pengembangan materi ajar sekolah dasar. Setelah pemberian konten dosen melakukan aktifitas pengasuahan pembelajaran melalui google classroom dengan memberikan penugasan, diskusi, dan tanya jawab mengenai penyelsaian proyek perkuliahan melalui LMS Google Class room. Saat yang telah tiba menurut perencanaan penjadwalan untuk tatap muka, maka akan digunakan untuk mahasiswa dalam menunjukan hasil kinerja proyeknya, membuktikan hasil kerja proyeknya dan melalukan elaborasi dan kerjasama dengan kelompok lainnya.

LMS Google Classroom ini adalah sebuah sarana ruang belajar yang dapat meningkatkan kemandirian belajar mahasiswa. Meskipun demikian, teridentifikasi juga bahwa tingkat kemandirian belajar mahasiswa belum sepenuhnya memenuhi harapan, sebab dalam beberapa hal seperti belum terbiasanya belajar dengan mengguankan sistem bukan tatap muka, dan masih dirasakan canggung dan tak nyaman belajar yang hanya berinterkasi dengan layar walaupun difasilitasi dengan hubungan internet untuk berkomunikasi, namun dari segi manjamen file untuk pengumpulan file ini dirasakan efektif krena struktur nya yang otomatis tertata dengan rapih. Oleh karena itu upaya-upaya untuk meningkatkan kemandirian belajar mahasiswa masih senantiasa perlu ditingkatkan salah satunya adalah dengan pembiasan pembelajaran mode Asynchronous ini. Memperhatikan pentingnya peningkatan kemandirian belajar mahasiswa ini, maka kepada bapak/ibu dosen disarankan untuk senantiasa berupaya membantu mahasiswa meningkatkan kemandirian mereka unutk bisa memulai pembiasaan baru dengan belajar moda asyncrounus dengan pemanfaatan LMS apaun yang bisa digunakan. Kurangnya kemandirian belajar mahasiswa di moda pembelajaran Asyncrounus merupakan masalah serius yang perlu segera diupayakan jalan keluarnya. Pengembangan kemandirian belajar pada mahasiswa di moda pembelajaran Asyncrounus memerlukan peran serta dosen dan desain pembelajaran dalam jaringan yang tepat untuk diterapkan. Dosen dapat memilih strategi perkuliahan yang dapat membantu meningkatkan kemandirian belajar mahasiswa di moda pembelajaran Asyncrounus yang salah satunya adalah dengan pemanfaatan LMS Google Classroom.

\section{KESIMPULAN}

Berdasarkan hasil penelitian yang telah dilaksanakan, diperoleh kesimpulan bahwa telah berhasil dikembangkan produk Desain Perkuliahan Pengembangan Materi Ajar SD Dengan LMS (Learning Management System) Google Classroom Untuk Meningkatkan Metakognisi Dan Produk Bahan Ajar Mahasiswa Calon Guru Sekolah Dasar FKIP UGJ di matakuliah pengembangan materi ajar SD dan Pengantar Pendidikan.

\section{ACKNOWLEDGMENT}

Penulis mengucapkan terima kasih kepada berbagai pihak yang telah membantu dalam penelitian ini. Penelitian ini didanai oleh Skema Riset Dosen Pemula (RDP) Universitas Swadaya Gunung Jati Cirebon tahun pendanaan 2020.

\section{DAFTAR PUSTAKA}

Cech, Pavel, Vladimir Bures, and V. N. (2004). E-Learning Implementation at University. In Procedings of 3rd European Confrence on e-Learning (pp. 25-34). Paris, France. Hanafin, M.J. \& Peck K.L (1988). The Design, Development and evaluation instructional software. New York: Macmillan Publishing Company. 
Hakim, Abdul Barir. 2016. Efektifitas Penggunaan E learning moodle, google classroom dan edmodo. I-Statment STIMIK ESQ. Volume 2 No.1

Farisi, Mohamad Imam, Abdul Malik. 2013. Pengembangan Desain Tutorial Online Pendidikan Ilmu Pengetahuan Sosial Model Siklus belajar di universitas Terbuka. Lembar Ilmu Kependidikan. Vol.42. Nomor 2.

Iftakhar, S. (2016). Google Classroom: What Works and How?. Jurnal of Education and Social Science, 2 (3) ,12-18

Kurniawan, Dede Trie. (2016). Profil literasi TIK (Teknologi Informasi dan Komunikasi) Mahasiswa Calon Guru Mateamtika di Salah satu Perguruan Tinggi Swasta Kota Cirebon. Proceeding Riksa Bahsa X "Literasi dan Budaya Bangsa". ISBN 978-60260080-0-8 Program Studi Pendidkan Bahasa dan Sastra Indonesia SPs UPI.

Latif, Abdul. Ahmad Al Yakin. Herlina Ahmad. 2019. Digital Classroom untuk meningkatkan kemampuan metakoginisi mahasiswa dalam pembelajatan Pkn. Celebes Education. Vol 1 No. 2

Mustaniroh, S.A. (2015). Penerapan Google Classroom sebagai Media Pembelajaran pada Pelajaran Kimia di SMK Negeri 2 Temanggung. Artikel Ilmiah, Salatiga: Fakultas Teknologi Informasi. Universitas Kristen Satya Wacana.

Pappas, Christopher (2015). "Google Classroom Review: Pros and Cons Of Using Google Classroom In eLearning". Diakses 1 Mei 2017 dari https://elearningindustry.com/google classroom-review-pros-and-cons-ofusinggoogle-classroom-in-elearning

Slavin, Robert E. 1992. Research Methods in education. New jersey. Prentice Hall International Inc.

Subriyantoro, Singgih. Ismail. 2017. Dampak Learning Management System (LMS) Pada Performarma akademik mahasiswa di perguruan tinggi. Edukaria: Jurnal Pendidikan dan Pembelajaran Vol. 2 (4)

Utami, Rini. 2019. Analisis Respon Mahasiswa Terhadap penggunaan Google Classroom pada matakuliah psikologi pembelajaran matematika. PRISMA: Proseiding seminar nasional matematika.

Viswanath Venkatesh, Michael G. Morris, Gordon B. Davis, F. D. D. (2003). User Acceptance of Information Technology: Toward a Unified View. MIS Quarterly, 27(3), 425-478.

Yapici, İ. Ü. (2012). The Effect Of Blended Learning Model On High School Students' Biology Achievement And On Their Attitudes Towards The Internet, 11(2), 228-237. 